\title{
"Trampantojo a lo divino": el Nazareno del Hospital de Jesús en Pensilvania
}

\begin{abstract}
$\mathrm{E}$ n la segunda mitad del siglo xvir una indígena cacique donó una escultura de Jesús Nazareno que había venerado en su casa a la iglesia del Hospital de la Concepción de Nuestra Señora de la ciudad de México. Transcurridos unos pocos años, el culto tomó proporciones mayores, a tal punto que el nombre del hospital cambió por el de Hospital de Jesús, con el cual todavía se le conoce. A medida que el culto al Nazareno creció, también lo hizo el fenómeno de las "copias", en el cual una efigie, por el respeto y devoción que por sus poderes milagrosos hubiera adquirido, se transformaba en "modelo" a seguir para los pintores que respondían a solicitudes específicas de los devotos.

El propósito de esta noticia es dar a conocer un cuadro novohispano que se conserva en el St. Charles Borromeo Seminary, en Wynnewood, Pensilvania, en las afueras de Filadelfia, y explicar porqué se cree que la pintura es un retrato pintado de esta devota escultura. ${ }^{\mathrm{I}}$ Para este efecto se describirá el lienzo de Pensilvania, revisando ciertas nociones del fenómeno de los retratos pintados de imágenes escultóricas, así como aspectos de la veneración al Nazareno del Hospital de Jesús. En particular me interesa llamar la atención sobre dos elementos precisos del cuadro del Seminario: unas transparencias en la túnica del Nazareno, y una mancha oscura en el lienzo. Ambos se pueden relacionar con el culto que recibía el Nazareno del hospital.
\end{abstract}

I. Quisiera agradecer tanto a Clara Bargellini, del Instituto de Investigaciones Estéticas, UNAM, por la noticia sobre este cuadro, como a Mark Castro y Terry Lignelli, del Philadelphia Museum of Art, quienes hicieron posible la visita al Seminario, y a Cait Kokolus, por su generosa hospitalidad durante dicha visita. 
El Seminario de San Carlos Borromeo posee una colección de alrededor de 250 pinturas que fue amasada mediante legados y donaciones. ${ }^{2}$ Lamentablemente se cuenta con muy poca información sobre la procedencia de dichas obras. El acervo es muy ecléctico: hay piezas que son verdaderamente obras maestras, pero muchas otras son copias por aficionados de obras afamadas. Debido a que el propósito del Seminario es ante todo la docencia y que no funciona como museo, no se ha publicado un catálogo de la colección, aunque existe un inventario. El lienzo del Nazareno (fig. I) lo donó monseñor Walter A. Bolwer, en 1972, ordenado en Filadelfia en 1924 y sacerdote en diversas parroquias de la diócesis. Se desconoce cuándo y en qué circunstancias tomó posesión del cuadro del Nazareno.

El lienzo de Pensilvania es anónimo y no ostenta fecha, pero por razones formales y de índole histórica, explicadas a continuación, se puede pensar que se trata de una obra de la segunda mitad del siglo xvir. El Nazareno está representado en el momento de una caída hacia el Monte Calvario. La figura se sostiene con la mano derecha, mientras con la otra sujeta la extremidad del cruce de la cruz; tiene la cabeza ligeramente volteada hacia la izquierda, con la mirada hacia lo alto; ostenta una soga al cuello y la doble corona. ${ }^{3}$ La efigie se encuentra sobre lo que parece una mesa de altar, con unas flores a sus pies y unos cortinajes en la parte de arriba. La pierna izquierda exhibe un buen dibujo y los paños, magnífica factura; en cambio la representación de la pierna doblada hacia atrás no es tan afortunada. ${ }^{4}$

La escultura del Nazareno del Hospital de Jesús, la cual considero copia pictórica representada en la pintura de Pensilvania, forma parte de las múltiples imágenes de gran veneración que conoció la Nueva España (fig. 2).5 La

2. Agradezco esta información a Cait Kokolus, comunicación personal, 6 de octubre de 2014 .

3. La doble corona está conformada por la de espinas y las “potencias", representadas por los tres resplandores labrados en plata, a los lados y arriba de la cabeza. Según Héctor Schenone, serían una simplificación de la aureola cruciforme y representarían las tres potencias del alma: entendimiento, voluntad y memoria. Véase Iconografía del arte colonial. Jesucristo (Buenos Aires: Fundación Tarea, 1998), 25 I.

4. Hubo muchos pintores hábiles en la escuela novohispana de la segunda mitad del siglo XVII, quienes podrían haber realizado este cuadro, pero no quisiera aventurarme en hacer una atribución formal. Rogelio Ruiz Gomar reconoció en el cuadro lejanos ecos de Cristóbal de Villalpando, pero una mayor cercanía con Baltasar de Echave Rioja. Agradezco esta información a Rogelio Ruiz Gomar, comunicación personal, I2 de diciembre de 2014.

5. Para más información sobre el Nazareno del Hospital de Jesús, consúltese: Alena Robin, 


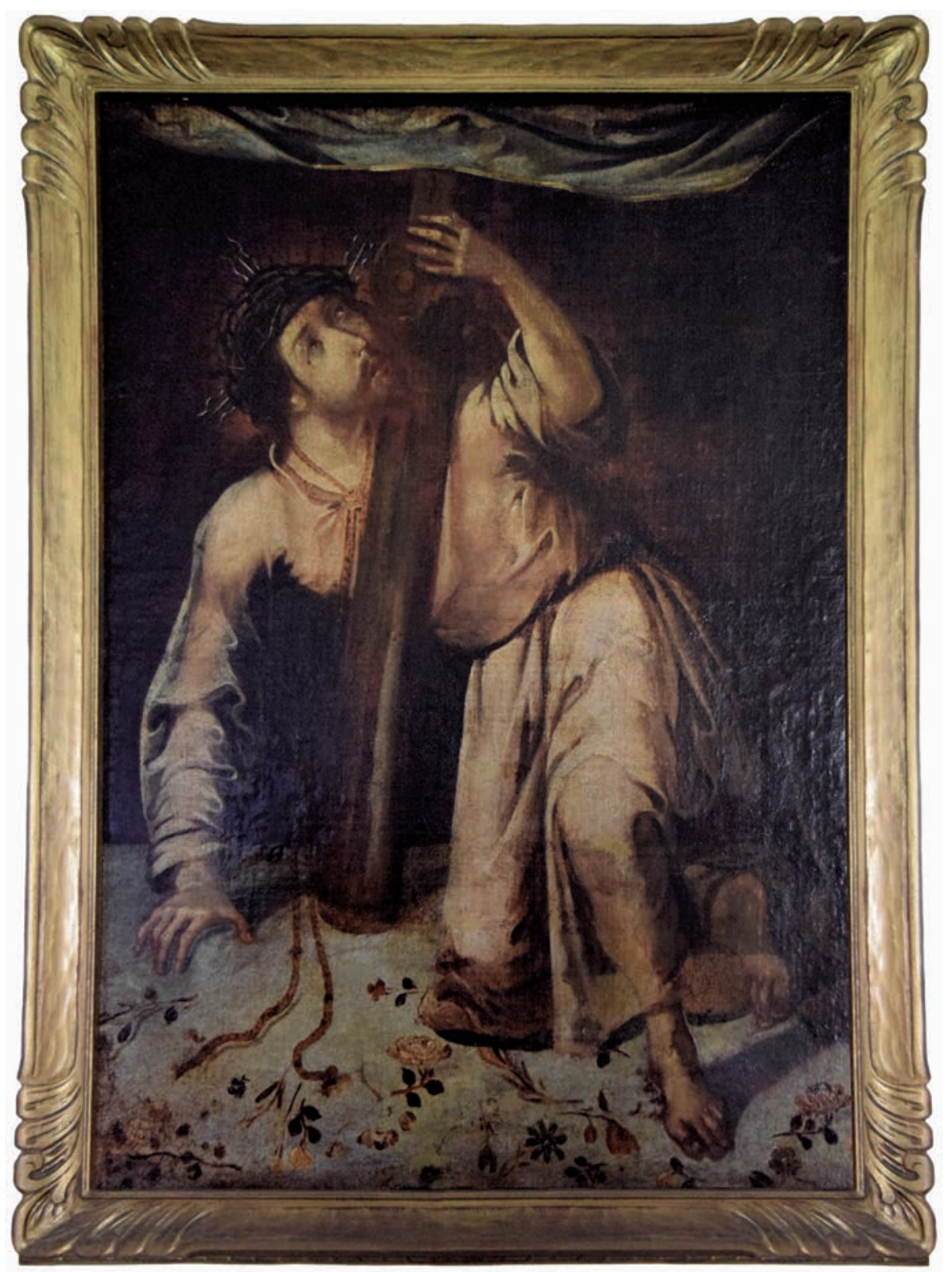

I. Anónimo, Nazareno, segunda mitad del siglo xviı, óleo sobre lienzo pegado a tabla, $96 \times 7 \mathrm{I} \mathrm{cm}$. "From the Collection of St. Charles Borromeo Seminary Wynnewood, pA". Foto: Alena Robin. 


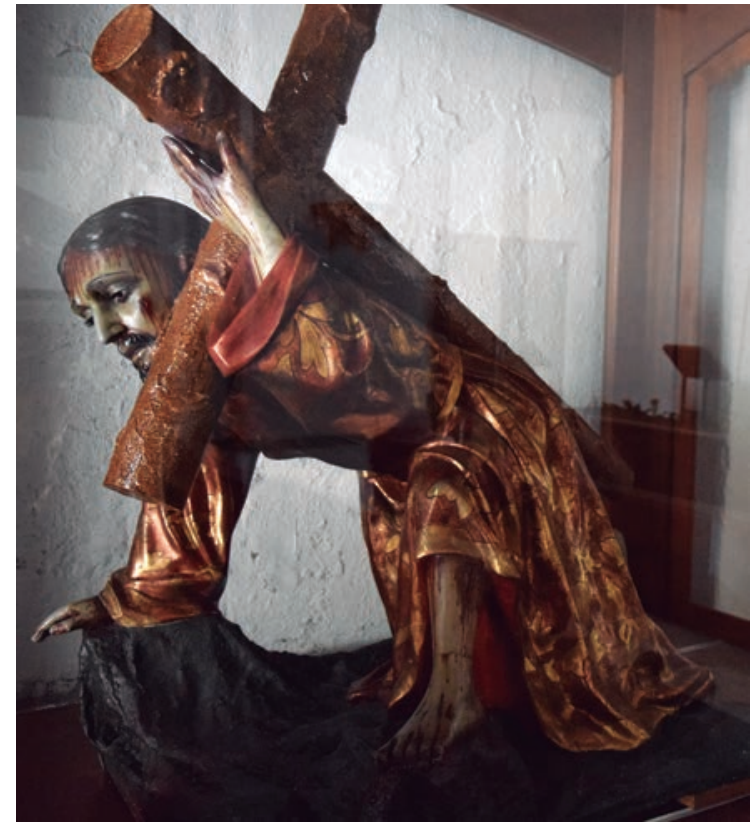

2. Anónimo, Nazareno, siglo XVII (?), escultura de madera policromada, ciudad de México. Hospital de Jesús. Foto: Alena Robin.

leyenda versa sobre una mujer indígena de nombre Petronila Jerónima, quien tuvo un sueño donde se le apareció una visión de Jesús que le causó una gran devoción: Cristo caído en su camino hacia el Calvario. ${ }^{6} \mathrm{Al}$ querer tener de bulto a la imagen sońada la solicitó a varios escultores, pero ninguno pudo lograr representar fielmente la efigie vislumbrada. No obstante, se cuenta que Dios quiso premiar su fe, y encaminó a su casa a unos indígenas que se decían escultores. Ellos lograron esculpir la efigie a la perfección, pero antes de pagar

"Los Cristos del México virreinal: sufrimiento, desnudez y sanción de imágenes", tesis de maestría en Historia del Arte (México: Universidad Nacional Autónoma de México-Facultad de Filosofía y Letras, 2002). También presenté una conferencia sobre el tema en Encrucijada, I Congreso Internacional sobre Escultura Virreinal, en Oaxaca, 2008, cuyas actas están en proceso de publicación. Una versión en inglés se publicará en el transcurso de 20I5: "A Nazarene in the Nude: Questions of Representation in Devotional Images of New Spain," número especial sobre "Living Images", Horti Hesperidum. Studi di storia del collezionismo e della storiografia artistica, en http://www.horti-hesperidum.com.

6. Lorenzo de Salazar Muñatones, Sermón a la peregrina, y milagrosa imagen de Jesús $\mathrm{Na-}$ zareno, del Hospital de Nuestra Señora de la Concepción de México, del señor marqués del Valle. Que predicó en 7 de septiembre de I664 (México: Viuda de Bernardo Calderón, I664). 
lo debido habían desaparecido misteriosamente. La indígena tuvo el Nazareno en el oratorio de su casa y antes de su muerte se echó a la suerte y se determinó que se donara al Hospital de la Concepción de Nuestra Señora, también llamado Hospital del Marqués, por ser obra fundada por Hernán Cortés a los pocos ańos de haberse consumado la Conquista. ${ }^{7} \mathrm{El} 3$ de marzo de 1663 se registró la entrada de la efigie a la antigua iglesia del hospital y pronto después el Nazareno empezó a obrar milagros y su fama fue creciendo exponencialmente, hasta sustituir el nombre del hospital. ${ }^{8}$

En términos estrictamente iconográficos, el Nazareno del Hospital de Jesús coincidiría más bien con una de las caídas de Jesús rumbo al Calvario, y no con su caminar hacia el Calvario, lo que usualmente se entiende por Nazareno, pues se le representa en el momento de una caída. Al comparar el lienzo del Seminario de Pensilvania con otros de temática similar, mismos que se mencionarán más adelante, se podrá apreciar que hay elementos visuales, ya no presentes en la escultura venerada hoy día, que permiten establecer nexos entre las obras.

Por otro lado, la iconografía de la efigie del Nazareno no tiene nada que haga de esta devoción algo típicamente americano como en el caso de otras imágenes de gran culto de la Nueva España, si no fuera por los principales agentes de la aparición de la imagen. Efectivamente, son indígenas los que tuvieron un papel principal no sólo en su revelación, en un sueño a una indígena cacique, sino también en su manufactura, pues los escultores que lograron rendir a la perfección esta visión eran asimismo indígenas. Resulta también interesante mencionar que el narrador de uno de los relatos tempranos de milagros obrados por el Nazareno, recién entregado al hospital, sea una indígena. ${ }^{9}$ Se trata de un conjunto de testimonios registrados en febrero de 1665 por encargo del sacristán del hospital, Antonio Calderón Benavides. ${ }^{10}$ Cada testimonio

7. Josefina Muriel, Hospitales de la Nueva España, t. I, Fundaciones del siglo xvi (México: Jus, 1956), 37-46; Eduardo Báez Macías, El edificio del Hospital de Jesús (México: Universidad Nacional Autónoma de México-Instituto de Investigaciones Estéticas, 1982), 49-50.

8. La fecha exacta de la llegada de la imagen al hospital proviene de la leyenda de un cuadro que ilustra el ingreso del Nazareno a la iglesia, véase Báez Macías, El edificio del Hospital de Jesús, figs. Iо y II.

9. Sobre el valor de los textos para la promoción de las imágenes milagrosas en Nueva España, véase Luisa Elena Alcalá, “¿Pues para qué son los papeles...?’ Imágenes y devociones novohispanas en los siglos XVII y XVIII", Tiempos de América, núm. I (I997): 43-56.

Io. Archivo General de la Nación (en adelante AGN), Hospital de Jesús, vol. 469, leg. 265 (2), exp. 24 , s.f. 
ofrece una versión del milagro ocurrido a la india Francisca Angelina, residente del barrio de San Miguel, cerca de Tlatelolco, quien tenía cuatro años de estar en cama, enferma de una llaga en una pierna, llena de gusanos, materia y sangre. Se narra el fallecimiento de la india, pero, después de horas de haber muerto, milagrosamente resucitó cuando una persona le acercó una estampa del Nazareno del Hospital de la Concepción, "con la cual se abrazó y le pidió le diese salud". Y no sólo se narra que la india resucitó gracias al Nazareno, sino que también sanó por completo. Todos los testigos tuvieron el acontecimiento por milagroso. ${ }^{\text {II }}$

En el caso de imágenes de gran devoción, se ha dado un fenómeno que Alfonso Pérez Sánchez ha llamado "trampantojos a lo divino", donde un cuadro piadoso representaba imágenes escultóricas como fieles réplicas, tal como se las veneraba en sus altares, acompañadas de sus accesorios, como cortinas, peanas, coronas, candelabros, floreros, y otros elementos de platería y joyería. ${ }^{\text {I2 }}$ Las copias permitían que la devoción de la efigie original se conociera más allá de la repercusión del culto inicial. La imagen en cuestión suele pintarse con una realidad compulsiva y una voluntad tridimensional, puesto que el objetivo de este fenómeno pictórico es que quien contemple el lienzo sienta, y

II. El 8 de agosto, el arzobispo Alonso de Cuevas Dávalos declaró que la información era bastante y suficiente para que fueran declarados los dos milagros obrados. Se debía celebrar una misa cantada con diácono y subdiácono, con sermón y procesión que saliera de la iglesia por una de sus puertas y entrara por la otra: "Y se haga el regocijo que se pudiese de luminarias, atabales y trompetas, con lo demás de fuegos que la devoción de quien los hiciere pudiere obrar”. También, un notario de la Audiencia y Juzgado Arzobispal tenía que hacer notorio el auto en el púlpito de la iglesia. A petición del capellán Antonio Calderón, se concedió licencia para que lo contenido en la relación se ilustrara en una pintura en la iglesia; se desconoce si se realizó, y de ser así, se ignora el paradero actual. Véase AGN, Hospital de Jesús, vol. 469, legajo 265 (2), exp. 24 , s.f.

I2. Alfonso Pérez Sánchez, “Trampantojos a lo divino”", Lecturas de Historia del Arte, núm. 3 (1992): I39-I55. Existe una abundante bibliografía sobre este fenómeno en la América hispana. Consúltese, entre otros, el siguiente estudio que, si bien considera el fenómeno en los Andes, contiene varios aspectos comunes a esta tradición pictórica: Maya Stanfield-Mazzi, Object and Apparition. Envisioning the Christian Divine in the Colonial Andes (Tucson: The University of Arizona Press, 2013), en particular el capítulo 7, "Statue Paintings", I37-175. Sobre las posibilidades de trampa y engaño de la pintura, Victor Stoichita establece, a partir de la lectura de un pasaje de Antonio Palomino, un catálogo abreviado de las posibilidades ilusionistas de la misma, como: escultura, prolongación del espacio o de la luz real, o objeto engańoso, o resultado de una visión. Véase El ojo mistico. Pintura y visión religiosa en el Siglo de Oro español (Madrid: Alianza Editorial, 1996), 66. 
piense que se halla en presencia de la escultura original y participe de alguna manera del poder que ésta había adquirido. Estas imágenes se convierten así en sustituto afectivo de la figura ausente y ante la copia los devotos se sienten asistidos como si estuviesen frente a la efigie misma. ${ }^{13}$ En algunas ocasiones las copias eran efectivamente tocadas al original y así se pensaba que el sustituto tenía la misma capacidad que la que sirvió de modelo para obrar prodigios. En ciertos casos, una cartela a los pies del fingido altar de la pintura confirma que se trata de un "fiel retrato" de una imagen en particular, por lo cual a este género también se le ha denominado "verdadero retrato" o "réplica exacta". Cuando no se encuentra tal información, la escenografía permite por lo común pensar que se trata de un "trampantojo a lo divino". Es decir, no sólo se imitaba fielmente la hechura verdadera, sino que se simulaba su emplazamiento original para generar el espacio real. Sin embargo, no siempre se puede identificar con facilidad la imagen copiada si no se tiene una iconografía bien determinada, y creo que es el caso del Nazareno del Hospital de Jesús. En efecto, la efigie del hospital de la ciudad de México no fue el único Nazareno que recibió un culto popular durante el virreinato, si bien tal vez fuese el más famoso. Entonces, ¿̇cómo atestiguar con certeza que el lienzo de Pensilvania sea una copia de la imagen del Hospital de Jesús?

Algunos documentos históricos atestiguan el parentesco de por lo menos dos ejemplos escultóricos con el Nazareno del Hospital de Jesús: el Nazareno de Tlalmanalco (fig. 3) y El Divino Indiano en Chiclana de la Frontera, Espańa. En el caso de Tlalmanalco, en el contrato fechado en I694 para la ejecución de un retablo lateral con la advocación de Jesús Nazareno en la iglesia de San Luis Obispo, se especificaba que la escultura de bulto del retablo se había de hacer "según el que está en el Hospital de Nuestra Seńora de la Concepción, según los tamaños". ${ }^{14}$ En el ejemplo conservado en España, se sabe que la escultura se encontraba primero en la ciudad de México. ${ }^{\text {Is }}$ Llegó a España

13. Sobre esta idea, véase Sergi Doménech García, "Función y discurso de la imagen de devoción en Nueva España. Los 'verdaderos retratos' marianos como imágenes de sustitución afectiva”, Tiempos de América, núm. I8 (2011): 77-93.

14. Archivo General de Notarías, Joseph de Anaya y Bonillo, ciudad de México, 7 de julio de I694, núm. I3, ff. 9Ir-93v, reproducido en: Elisa Vargaslugo, Gustavo Curiel et al., Juan Correa, su vida y obra. Cuerpo de documentos, t. III (México: Universidad Nacional Autónoma de México-Instituto de Investigaciones Estéticas, 199I), 93-94.

15. El fascinante caso de esta efigie se narra en Pablo F. Amador Marrero, "Prenda de santa estima. El Divino Indiano de Chiclana de la Frontera, Cádiz: una escultura ligera singular”, 
I64 ALENA ROBIN

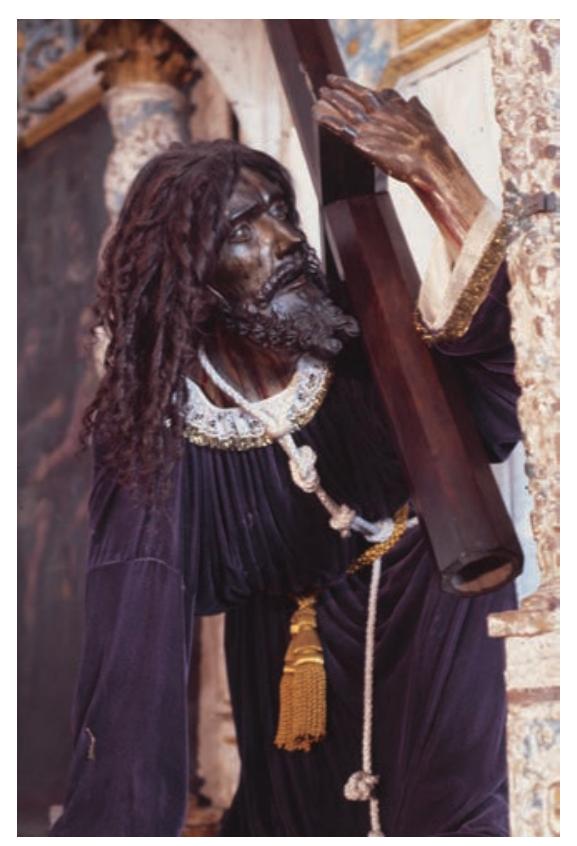

3. Anónimo, Nazareno, detalle, I694, escultura de madera policromada, Tlalmanalco, Estado de México. Iglesia de San Luis Obispo. Foto: Cecilia Gutiérrez Arriola, Archivo Fotográfico Manuel Toussaint, IIE-UNAM.

a finales de 1674 gracias al comerciante Julián Cortés, quien lo ofreció al convento de monjas agustinas de Chiclana de la Frontera. La imagen había pertenecido originalmente al tío de su esposa en la ciudad de México, quien la había tenido en su oratorio privado hasta su muerte.

Existe un lienzo de un Nazareno de bulto que se encuentra en la actualidad en las colecciones del Museo Soumaya en la ciudad de México, el cual ilustra bien la confusión que puede existir con el fenómeno de las copias pictóricas de imágenes escultóricas de devoción cuando la pintura no establece textualmente ser un "verdadero retrato" de algún original (fig. 4). El Nazareno está arrodillado con la pierna derecha hacia el suelo, sosteniendo la cruz con la mano izquierda. Unas pesadas cortinas están abiertas y revelan la

en Amans artis, amans veritatis. Coloquio Internacional de Arte e Historia en Memoria de Juana Gutiérrez Haces, ed. Gustavo Curiel (México: Universidad Nacional Autónoma de MéxicoInstituto de Investigaciones Estéticas, 20II), 207-26I. Pablo F. Amador Marrero está preparando un estudio más extenso sobre esta copia escultórica del Nazareno del Hospital de Jesús de la ciudad de México, conservada en España. 
4. Anónimo, Jesús Nazareno, segunda mitad del siglo XvII, I60 × IIo cm, óleo sobre lienzo, ciudad de México. Museo Soumaya.

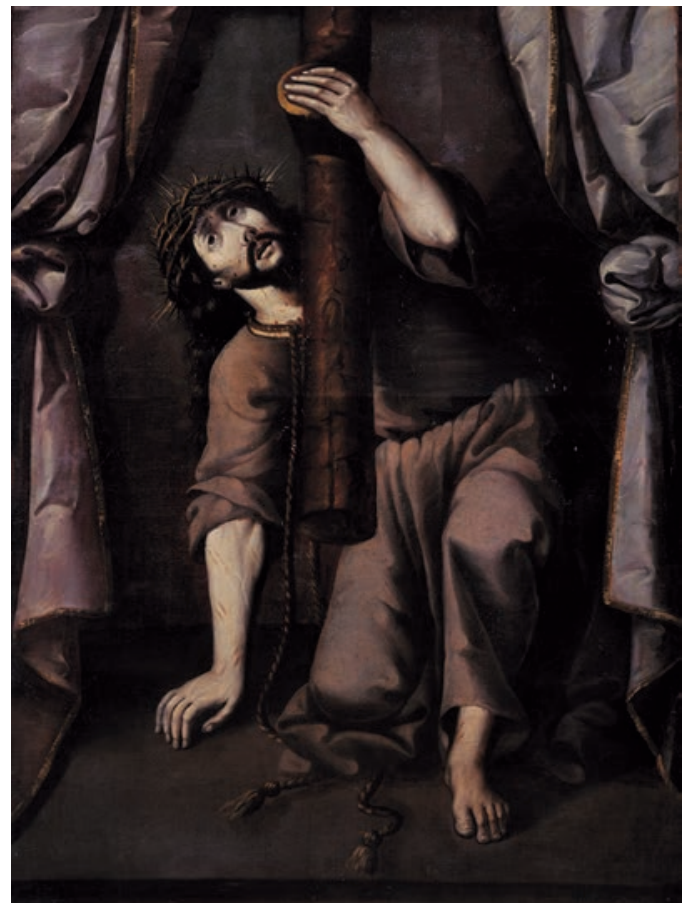

imagen. ${ }^{16}$ Con una soga al cuello y doble corona tiene el rostro ligeramente volteado hacia la izquierda y los ojos mirando hacia arriba. No obstante, en el caso de la obra del Soumaya el cuadro se ha relacionado con la efigie del Hospital de Jesús por la gran devoción que llegó a tener la escultura. ${ }^{17} \mathrm{Si}$ bien la pintura es anónima, Rogelio Ruiz Gomar reconoció en ella características y calidades dignas de la pintura de la segunda mitad del siglo XVII y lo atribuye a un seguidor de José Juárez, ya sea Antonio Rodríguez, Pedro Ramírez, o Baltasar de Echave Rioja. Subrayó el hábil juego de luces y sombras, el volumen de la figura, y el vigoroso manejo de las telas.

I6. Mark Castro y Terry Lignelli comentaron sobre la posibilidad de que hubieran cortado el lienzo del Seminario (fig. I) de arriba y tal vez también de los lados. De ser así, las cortinas podrían ser también un elemento visual que relacione ambas composiciones pictóricas. Sobre la función de los cortinajes en este tipo de imágenes devocionales, véase Doménech García, "Función y discurso de la imagen", 86; Stanfield-Mazzi, Object and Apparition, I59-I60.

17. Rogelio Ruiz Gomar, "Jesús Nazareno", Tesoros del Museo Soumaya de México siglos XVIXIX (Madrid/Bilbao: BBVA, 2004), I42-I44. 
La pintura del Museo Soumaya tiene similitudes con el lienzo del Seminario de St. Charles Borromeo. La postura de la imagen, la manera en que sostiene el madero, la mirada volteada ligeramente hacia la izquierda, y viendo apenas hacia arriba, el uso de cortinaje para enmarcar la efigie, la doble corona, y la soga al cuello: todos éstos son elementos muy parecidos tanto en el lienzo del Soumaya como en el del Seminario, lo cual podría indicar que es probable que se relacione con la misma imagen de bulto. Serían éstos entonces los aspectos distintivos de la iconografía del Nazareno del Hospital de Jesús, repetidos de una composición a otra. ${ }^{\mathrm{I}}$

No obstante el parecido entre ambas representaciones pictóricas, quisiera llamar la atención sobre un detalle que las distingue: la túnica del Nazareno. Desde la época colonial muchas imágenes escultóricas, a pesar de ser de bulto redondo, se vestían con ropaje encima de la talla policromada por cuestiones de devoción. La túnica del Nazareno del Soumaya es de un color que oscila entre café y gris, en vez de la tradicional túnica morada que se suele usar para este momento, tal vez debido al paso del tiempo que intervino para degradar el color (fig. 4). Por otro lado, el color de la túnica del Nazareno del Seminario es más bien un rosa blanqueado (fig. I). Este detalle podría aludir a un cambio de indumentaria de la efigie entre el momento de hechura de ambos lienzos, mas no a que se refieran a una escultura diferente. Además, si se observa con detenimiento la túnica del Nazareno del Seminario, se puede notar que el rendimiento ofrece veladuras en la aplicación del óleo en la túnica, concentradas en dos partes: en la manga derecha (fig. 5) y al nivel de la pierna izquierda. Quisiera proponer que la transparencia de la túnica es intencional y hay una razón histórica que definitivamente permite relacionar este lienzo con la milagrosa escultura del Hospital de Jesús.

En efecto, en marzo de 1665 , el Nazareno del Hospital de Jesús fue acusado ante el Tribunal de la Inquisición por no llevar la túnica acostumbrada. ${ }^{\text {I9 }}$ Después de meses de discusión sobre este punto y otros detalles iconográficos, el Santo Tribunal comunicó a Antonio Calderón, sacristán de la iglesia a cuyo

I8. Este planteamiento está también relacionado con un lienzo de la misma temática de Antonio Torres, conservado en la iglesia del convento de las Descalzas Reales de Antequera, en Málaga, España, lo cual nuevamente confirma que la devoción al Nazareno del Hospital de Jesús se dio de ambos lados del Atlántico. Véase la figura i8 en Amador Marrero, "Prenda de santa estima”, 243.

19. AGN, Inquisición, vol. 604 ( $\mathrm{I}^{\mathrm{a}}$ parte), exp. 33, ff. I83r-I9Iv, del I7 de marzo de 1665 al 9 de marzo de 1665 . 
5. Anónimo, Nazareno, detalle, segunda mitad siglo XviI, óleo sobre lienzo pegado a tabla, $96 \times 7 \mathrm{I} \mathrm{cm}$, "From the

Collection of St. Charles Borromeo Seminary Wynnewood, PA". Foto: Alena Robin.

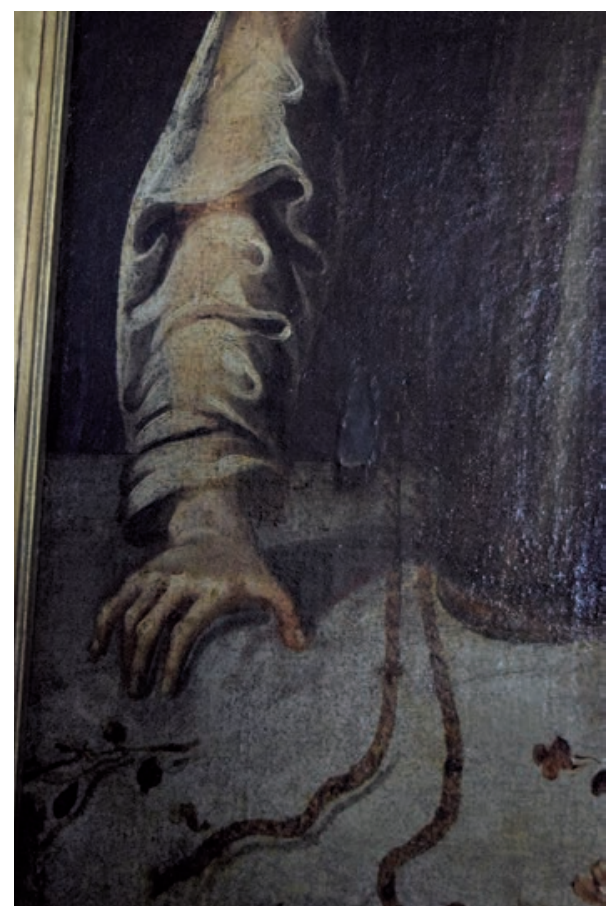

cargo se encontraba el culto de la imagen, la decisión a la cual habían llegado los padres inquisitoriales: se debía vestir al Nazareno con su túnica morada. No obstante, el sacristán quiso proponer otra solución: que la imagen se vistiera con un velo transparente de manera que se apreciaran las llagas de la espalda de la efigie. ${ }^{20}$ La Inquisición no accedió a su solicitud y se publicó un edicto para que en adelante todas las figuras del Nazareno se vistieran con la túnica morada. ${ }^{2 \mathrm{I}}$

Considero que se pueden encontrar rastros de las discusiones y preocupaciones del santo Tribunal en la pintura del Nazareno de Pensilvania. Las trans-

20. Por esta razón, considero que la escultura que se venera actualmente en el Hospital de Jesús no es la que originó tanta devoción en la segunda mitad del siglo xviI, pues tiene la vestimenta esculpida y ricamente policromada (fig. 2). Por su parte, Pablo F. Amador Marrero propone que se trata de la misma efigie, pero que ésta sufrió cambios a lo largo del tiempo hasta conseguir el aspecto actual. Son necesarios análisis científicos para confirmar esta sugerente hipótesis. Véase Amador Marrero, "Prenda de santa estima", 217.

2I. AGN, Inquisición, vol. 628, exp. 5, f. 98, 1665. 
parencias arriba mencionadas parecen ser intencionales y no resultado de una limpieza excesiva de la capa pictórica, pues están circunscritas a zonas específicas. ${ }^{22}$ Las veladuras, que permiten relacionar directamente esta pintura del Nazareno con la escultura del Hospital de Jesús y el caso de la Inquisición, que señalé antes, demuestran que el sacristán logró cumplir con la sentencia inquisitorial de vestir al Nazareno con su túnica y, a la par, ofrecer transparencia que dejara apreciar la anatomía de la escultura. En el Nazareno del Soumaya la manga de la túnica está recogida hasta el codo, lo cual hace posible ver algunas laceraciones sufridas por Cristo; lo mismo ocurre con parte de la pierna izquierda. Las transparencias de la túnica del Nazareno del Seminario, restringidas a ciertas áreas, parecen buscar el mismo efecto.

El Nazareno del Seminario incluye flores en la mesa de altar de la imagen las cuales, posiblemente, formaban parte de la ofrenda que se brindaba a la escultura, con la idea de recrear el lugar de culto original de la efigie. En este sentido, la ilusión pictórica difiere del lienzo del Soumaya que la sitúa en un ámbito ficticio ambivalente: se encuentra presente la mesa del altar, pero el simulacro está tan bien logrado al llegar al límite del lienzo pintado que parece ser un verdadero altar, invadiendo así el espacio real del espectador.

Más allá de los detalles pintados, como las flores y el cortinaje, el Nazareno de Pensilvania es un vivo testimonio de cómo la gente trataba de crear las escenografías en las cuales las imágenes veneradas tenían culto para recrear verdaderos "trampantojos a lo divino". Una mancha negra en el lienzo se encuentra debajo del brazo derecho del Nazareno, entre éste y el madero de la cruz, a la altura del altar (figs. I y 5). Para entender esta "imperfección" del lienzo del Seminario hay que tomar en cuenta un grabado fechado en 1716 , procedente del Archivo General de la Nación, donde con claridad se identifica en la cartela de la estampa al Nazareno del Hospital de Jesús (fig. 6). Los impresos también participaron ampliamente de este fenómeno de las copias para difundir y fortalecer el culto de la imagen de devoción, jugando de la misma manera con las funciones de réplica y reemplazo. ${ }^{23} \mathrm{El}$ grabado, conservado en el archivo, es particularmente interesante, pues atestigua con contundencia el aspecto que tenía la imagen original del Nazareno y el entorno en el cual se veneraba en el Hospital de Jesús a principios del siglo XVIII.

22. Agradezco esta información a Mark Castro y Terry Lignelli. Es necesario, no obstante, hacer un estudio más profundo sobre el estado de conservación del cuadro.

23. Véase Doménech García, "Función y discurso de la imagen". 


\section{$\oplus$}

DOI: http://dx.doi.org/10.22201/iie.18703062e.2015.107.2557

“TRAMPANTOJO A LO DIVINO”

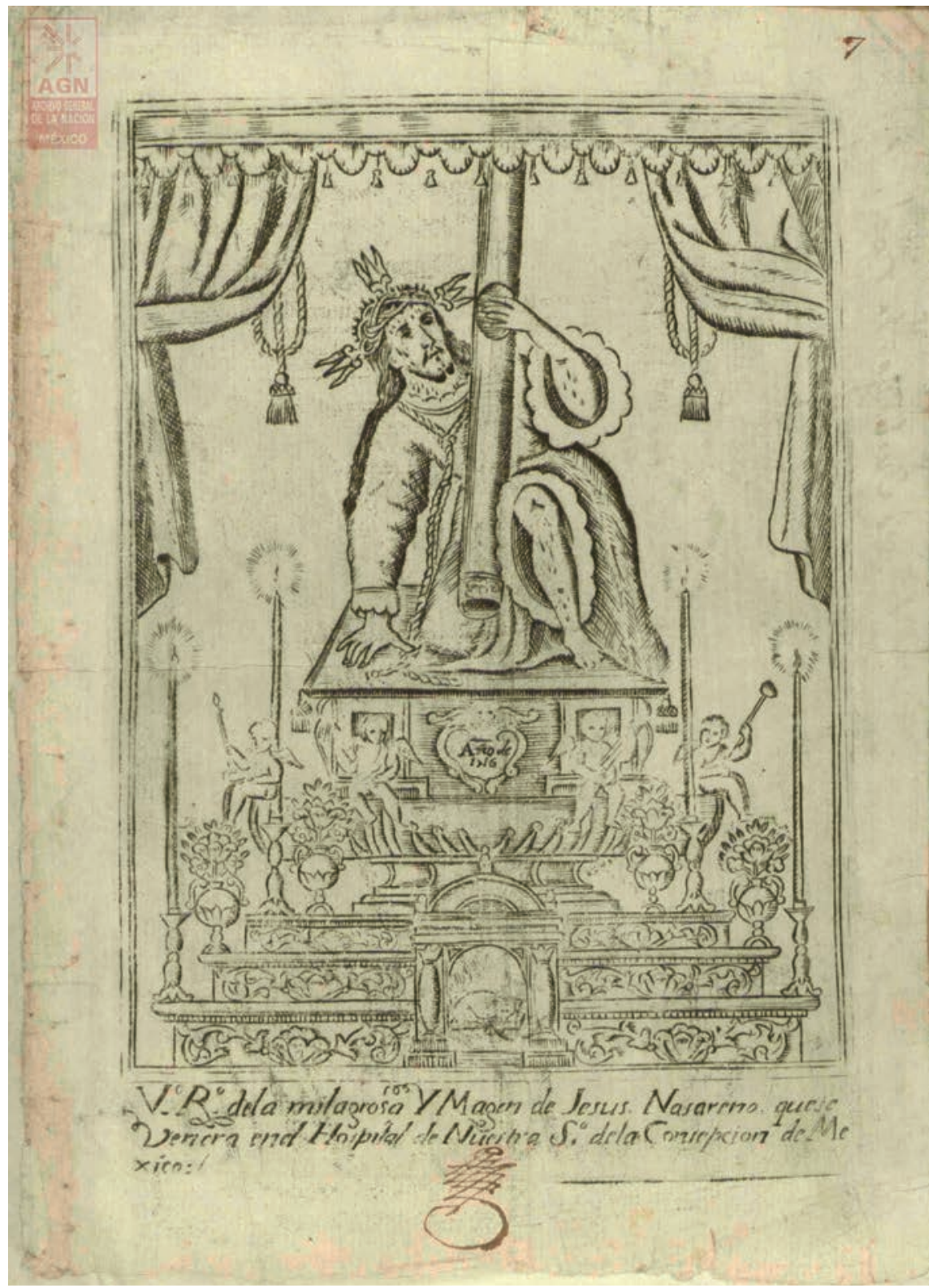

6. Anónimo, Verdadero retrato de la milagrosa imagen de Jesús Nazareno que se venera en el Hospital de Nuestra Señora de la Concepción de México, I716, grabado, ciudad de México. Archivo General de la Nación, Criminal, vol. 716, exp. 17, f. 243. Foto: AGN. 
El Nazareno del grabado está colocado sobre una peana, enmarcada por cortinajes. Sostiene la cruz de una manera muy parecida a las representaciones del Soumaya y del Seminario. Otros detalles como la cabeza mirando hacia la izquierda, la doble corona, la soga al cuello, las heridas en el antebrazo y la pierna establecen una fuerte conexión visual entre las tres obras (figs. I, 4 y 6). Estos elementos, que se repiten de una composición visual a la otra, permiten asociarlas con el original. Sólo en el grabado se pormenoriza la peana en la cual se encuentra la efigie. Este detalle tiene su importancia: el grabado responde a un culto más íntimo, donde fácilmente el devoto podría rezar a la imagen sosteniendo la estampa en sus manos. Los cuadros, mucho más grandes, permitían una escenografía mayor: se puede pensar que el lienzo estuviese colocado encima de una estructura que simulara la peana del Nazareno del Hospital. Ésta, en el grabado, está ricamente ornada de ángeles, floreros y veladoras, elementos que concedían una teatralidad muy del gusto del barroco hispano. Las veladoras de la estampa son, considero, las que se relacionan con la mancha oscura del lienzo del Seminario: es posible pensar que se trate de una quemadura causada por una candela encendida, depositada sobre una plataforma que fingiera la peana del Hospital, que, al estar demasiado cerca de la pintura, causara daños en la capa pictórica (fig. 5). El perfil mismo de la sombra aparenta la forma de la llama de una vela encendida. Las veladoras, lámparas y aceite eran elementos fundamentales para la iluminación de estas imágenes de gran devoción y los fieles participaban con donaciones. ${ }^{24}$

El caso de la pintura del Nazareno del St. Charles Borromeo Seminary se inscribe dentro de los ejemplos de "trampantojos a lo divino" y responde a la necesidad de tener copias pintadas de una imagen devocional para cumplir con el culto en otro ámbito. Cómo y cuándo llegó este lienzo novohispano a Pensilvania es una incógnita pendiente por resolver, pero atestigua el culto que recibió la efigie del Hospital de Jesús a poco tiempo del caso de la Inquisición, pese a haber sido objeto de un edicto del Santo Tribunal que lo mandó cubrir con una túnica morada. Si bien la exhibición de la efigie original podía variar constantemente mediante nuevas ofrendas, la copia pictórica de la escultura cristaliza un develamiento fugaz de la misma. ${ }^{25}$ Por tanto, se puede pensar que el lienzo del Seminario es un testimonio muy específico

24. Stanfield-Mazzi, Object and Apparition, I6I.

25. Por esta razón no hay dos "trampantojos a lo divino" exactamente idénticos, si bien comparten elementos iconográficos básicos. Véase Stanfield-Mazzi, Object and Apparition, I39, I5I. 
de este momento histórico en el cual el sacristán quiso vestir la escultura del Nazareno con un velo transparente para que se pudieran apreciar las llagas de la espalda. El pintor que realizó este encargo entendió perfectamente la solicitud de su comitente, sea quien fuese, aunque me gustaría sugerir que quizá se trataba de alguien cercano al entorno del sacristán. ${ }^{26}$ Por ende, la transparencia apreciada en la manga de la túnica del Nazareno tiene una explicación que responde a un contexto histórico muy preciso y contribuye a fechar esta obra cerca de I665. La quemadura que se puede apreciar en el lienzo es también parte de la historia del cuadro. Es una evidencia del culto que se daba alrededor de estas obras devotas, aunque fueran copias del original. \$े

26. Sobre la función social de este tipo de pintura, véase Stanfield-Mazzi, Object and Apparition, I7I-I75. 